\title{
Student Character Development Model of Environmental Care Halal Tourism in East Lombok
}

\author{
Wilda Syukria \\ Master Program of Geography Education \\ Faculty of Social Science, Universitas Negeri Padang, INDONESIA \\ Email: wildasyukria18@gmail.com
}

\begin{abstract}
The purpose of this research analyzes the factors forming of environmental care students the character in the halal tourism at East Lombok Regency. This research includes qualitative descriptive using Analytical Hierarchy Process (AHP) approach (Saaty, 2008). The data collection technique used purposive sampling and Analytical Hierarchy Process (AHP) through observation, interview, questionnaire (questionnaire) and literature study. The research informants were teachers, students, and principals of East Lombok. Data analysis technique was done by data reduction, data presentation, and conclusion. The result of research of factor forming the character of the students of environmental care in the halal tourism area in East Lombok 1) "Ulama / Tuan Guru" has a very high position for the order of life in East Lombok Regency. They were become the role model of life example given in accordance with syariat Islam and pay attention to the environment. 2) Parents are the environment that shapes the character of the child so that it can be applied in the life of society. 3) Teachers can develop positive characters in students through extracurricular activities as well as foster a sense of environmental care. 4) The government has an important role in disseminating to the public about halal tourism but the community retains the existing character in people's lives without changing the existing order. 5) The community is the person who is involved in the activities that exist in the life that consider the environmental conditions to remain beautiful and far from the word dirty to be an example of the community of a region with one community in other areas, especially in East Lombok Regency.
\end{abstract}

Keywords: Model, Character Cares Halal Tourism

\section{Introduction}

West Nusa Tenggara (NTB) is one of the provinces in the eastern part of Indonesia, located on the island of Lombok in Mataram city as the provincial capital. Lombok island has a natural beauty that is different from Bali to be the main attraction for tourists to visit Indonesia. The charm of the beauty of the famous Lombok includes Pink Beach, Senggigi Beach, Pura Batu Bolong, Segera Anak Lake, Rinjani Mount, Gili Trawangan, Seger Beach, Mandalika Beach, Benang Kelambu Waterfall, Bukit Merese, Sade village. In generally Indonesia residents are predominantly Muslim, specially Lombok Island predominantly Muslim population and is known as "the island of a thousand mosques" and yes icon (Sulhaini et al., 2017).

In addition, natural beauty and strong religious teachings held by the people of Lombok, the government promotes or introduces it to all over the world by developing Lombok as a halal Islamic tourism destination (Sulhaini et al., 2017). Indonesia in 2015, especially the island of Lombok awarded as the best halal tourist destination in the world and in 2016 was awarded World's Best Halal Honeymoon Destination and the 1st World's Best Halal Tourism Destination from World Halal Tourism Award (Firdausi et al., 2017). The halal tourist destination is a travel activity undertaken by Muslim tourists visiting a certain place for recreational purposes within a certain time in accordance with Islamic Syariat (Dogan, 2010 in Duman, 2011). Halal means anything that is free from danger and unlawful for the physical and human needs of human beings both in terms of getting it and its processing. Halal tourist attraction in the form of provision of tourist 
destinations like the form of hotels, restaurants, and places of worship are hygienic that meet the halal certification requirements.

Indonesia has an ethnic diversity that creates a different culture from region to other regions. The public generally respects local cultures still uphold the legacy of the ancestors. The culture of each region in Indonesia has a special attraction for tourists to visit it, one of them is Lombok island. Lombok Island with the largest ethnic group are Sasak with language Sasak Muslim majority and still a very strong tradition. A tradition that embraces and be able to safeguard the environment. Customs and traditions that exist in society, especially Lombok Sasak tribe already hereditary implemented are reflected in everyday life and in public (Kumbara, 2008).

The tourists which are come to Lombok would bring change to society, both in terms of livelihood, habits and customs, and culture. Through the education provided in schools, communities develop all the knowledge and skills they had for the family's economic progress, one of which sells handcrafted and become a snare for tourists. The Government has successfully introduced Lombok to the outside world so as to increase the income of the people of Lombok. Travelers also affect the character of a group or several groups. One of them is affecting the character of the students who get an education because one character formation is also influenced by the environment. Educational institutions not only provide a place of knowledge, but also a place to form the attitudes, behavior, character, and leadership of the nation's next youth (Rokhman et al., 2014).

The character is innate as human-specific elements including nature, hearts, souls, and behaviors that distinguish between one and another person that's applied in everyday life (Rokhman et al., 2014). It is very important and fundamental for a person in determining the future (Dianti, 2014). The social life through which a person starts from the family and community environment gave birth to a character (Fahmy et al., 2015). Good character will be born in the education environment in accordance with the teachings that given by the teacher called character education. Basically, character education is education values that include aspects of knowledge (cognitive), feeling, and action (Goleman, 2001 in Paneand et al., 2016). Components good characters owned by students include; (moral awareness, moral knowledge, moral judgment, making decision and self-awareness), moral feelings (conscience, self-confidence, empathy, kindness, self-control, and humility) and moral action (judging by ability, desire and practice) (Paneand et al., 2016). According to Law No. 20 in 2003 on National Education System, Article 1 that the purpose of national education is to develop the potential of students to have intelligence, personality and noble morals and, Article 3 says that the goal of national education is to develop the ability and form the potential of students to become human who is faithful and devoted to God Almighty, have a noble character, healthy, knowledgeable, capable, creative, independent, and become citizens of democratic and responsible. The values of the characters that should be implanted in the students according to the Ministry of National Education, the research and development body, the curriculum center has formulated the character education materials which include the following: 1) religious, 2) honest, 3) tolerance, 4) discipline, 5) hard work, 6) creative, 7) independent, 8) democratic, 9) curiosity, 10) spirit of nationality, 11) love of the homeland, 12) appreciate achievement, 13) friendly / communicative, 14) peace, 15) reading, 16) social care, 17) environmental care, and 18) responsibility (Zamroni, 2011).

Environmental care characters is an attitude and actions of a person who seeks to preserve the environment to pay attention to the damage caused to the environment (Al-Anwari, 2014). Students are expected to improve the quality of the environment, raising awareness and initiatives to combat the environmental damage that can be enjoyed continuously without damaging situation. Students and school community consider the condition of the school environment, both from outside and from inside the school. Activity concerned about the environment is done individually and collectively first so that all parties benefit. 
One of them concerned about the environment of the student in halal tourism area in East Lombok. School environment greatly influences the formation of good student behavior in the classroom and outside the classroom (Shernoff, 2016).

Students can change the existing conditions by the outside organization of school and delivery of information to parents to pay attention to the environment, one of them starting from the family environment, school and community. Students are able to give their parents an idea of the clean environment in the recreation area of East Lombok by paying attention to the cleanliness of the toilet, mosque, garbage, and attention to the cleanliness of food provided and sold. Students are able to tell their parents to hear the delivery of teachers at school so that their parents are working on the government can convey and consider the environmental conditions that exist in tourist areas of East Lombok Regency. Student actions carried out in the school to care for the environment such as toilet, throw garbage in its place, clean the schoolyard, do not pick flowers in the school park and do not damage the existing facilities in school (Al-Anwari, 2014). One place to form the character of students to more easily socialize and interact with many people, not just a place to print student excellence and achievement-oriented but also moral values school. In this globalization era, the character of a student has been waning for students in terms of knowledge can be said to be able to compete with the outside world. However, in terms of character need to reform the back for students overall.

\section{Method}

The type of this research was descriptive qualitative by using Analytical Hierarchy Process (AHP) approach (Saaty, 2008). The data collection technique using purposive sampling and Analytical Hierarchy Process (AHP) through observation, interview, questionnaire and literature study. The subjects of the study were teachers, students, and principals in the area of halal tourism in East Lombok Regency. Data analysis technique was done by data reduction, data presentation, and conclusion. The use of Analytical Hierarchy Process (AHP) was to select alternatively or to arrange alternative priority of character development model of the student in SMAN 1 Terara of East Lombok Regency.

\section{Results and Discussion}

Lombok as halal tourism destinations become an attraction for tourists to visit Indonesia that caused by the beauty of nature and the environment. A clean environment is certainly making that area into a beautiful and comfortable becomes one of the pull factors for a person to visit. The cleanliness of the surrounding environment would not be separated from the influence of the successor generation of people, namely students. Students are the future generation that formal education would take effect and changes in the surrounding environment. Schools of education are not only required to provide a wide range of knowledge that is very fast growing, but also required to develop the skills, expertise, form a moral, personality, character and even learners are required in order to have a wide range of skills required to meet world of work (Lubis, 2015).

Based on observations and interviews previously, it has been established first from the family environment, playground and community environment. All of the students action still need direction from the teacher as an advisor, coach and mentor at school (Arthur, 2011). While existing characters from the family environment, among others; honest, caring for others, respectful, responsible and fair (Sobri, 2015). Characters are developed through cycles of awareness, judgment, intention, behavior, and reflection (Alzola et al., 2012 in Sturm et al., 2016). Important roles affecting the students' character to care for the environment are encouraged by "Alim Ulama/Tuan Guru”, government and parents. "Alim Ulama/Tuan Guru" was an influential person in the activities held in East Lombok because the majority of religion in East 
Lombok is Islam. "Tuan Guru" is a person who strongly resists the teachings of Islam and implements them in life and calls for a better direction so that the whole society competes for good and exemplifies good character to school-aged children so as to have a positive impact.

In addition to the role of "Alim Ulama/Tuan Guru", the government and parents, the formation of students' character are concerned about the environment also in the form of a school environment. In keeping with the current Curriculum 2013, it helps teachers to instill faded spiritual, social and cultural values to the students. Students were able to compete with the outside world in terms of knowledge, but with the planting of characters was not necessarily all students were said to be good. Teachers as parents in school for students are a source of learning and utilization for students (Rolina, 2014). The teacher was an example for the students, such as the attitude of caring about the environment with the rules made by the teachers and obeyed by all the school people such as mutual cooperation, clearing the school plantation, not crossing out and damaging the school facilities and infrastructure. Through small things like this have given good character to the students to pay attention the condition of the environment. Character education gained by students in formal education positively impacts both personal, family and country as the next generation (Zuchdi et al, 2010).

Character building in schools, especially in East Lombok Regency was a formed from teaching and learning process by embed religious, cultural and social values. At the beginning of the lesson, the student was introduced to thank God for the blessings that have been given. Lesson associated with religious values as well as verses of Qur'an which discuss the material being taught. Planting given by teachers in accordance with the curriculum used in the present time, namely the curriculum in 2013 prioritize the formation of character, the reality on the ground decreased the quality of life of society, both morally and mentally, especially the younger generation (Marlina, 2013). Character building of students concerned about the school environment that involves all elements of the school without exception. The element of the school was responsible for the cleanliness of the school. The condition of the school was clean and beautiful to make students' comfortable and peaceful doing the learning process. The condition of the surrounding environment affects the students receiving the lesson. In addition, teachers form the character of the students through extracurricular activities including the caring attitude toward the environment (extension of teaching and learning in the classroom) (Tahir et al., 2013).

People are very respectful of "Alim Ulama/Tuan Guru" who play an important role in social life of society, especially in Lombok. "Alim Ulama/Tuan Guru" is a person who has many experiences in various things and people who elder in a society. The attitude of a student at the school is shaped by the teacher so that it becomes a habit of concern for many people, one of them "Tuan Guru". Students who make mistakes are very embarrassed to meet "Tuan Guru". They give a good attitude and behavior even though Lombok is now a halal tourism area and still maintain Islamic values. The main priority to be the environmental caring characteristic of Alim Ulama for East Lombok Regency by giving greening activities to the barren forest by inviting the pesantren children to plant trees. This action has a positive impact on the people of East Lombok Regency both in terms of community income, social conditions of students who work together and cleanliness of the surrounding environment (Orenstein et al., 2017).

\section{Parents}

Parents are the most important form of student character. They are the first people known their children in their lives. Psychological education of a child depends heavily on parental attitudes. Children are like blank papers depicted by parents that reflect the life of their family. All the actions of parents become role models for their children. One form of the courageous character of a child, if his parents form a brave character towards his son, they will be brave in accordance with the character given by parents to their 
children. The prominent activity is to educate the child to maintain the cleanliness of the environment, such as sweeping the house, floating the floor, disposing of the garbage in place so that it becomes the habit of a child and can be applied by the child wherever he is. Parents should also understand the changing conditions that occur to their children both in family life, playmates, and the surrounding environment in order to avoid acts that are beyond the control of a child (Vasilyeva et al., 2016).

\section{School/Teacher}

The character of the student is also shaped through the interference of an educator who is informal education other than the parent at home namely the teacher. Students spent the time at school rather than at home, so the school becomes the second home for students. Teachers are able to create competent students with the education provided at school, not just knowledge, but also have good character (Ülger et al., 2014). A good character encompasses understanding, care, and action based on core ethical values that seek to develop throughout the cognitive, emotional, and behavioral aspects of moral life (Ramdani et al, 2014). Students who have a noble character possess knowledge of her potential such as; reflective, confident, rational, logical, critical, analytical, creative and innovative, independent, healthy life, responsible, love science, patient, cautious, willing sacrifice, courageous, trustworthy, honest, hearts, shame to do wrong, forgiving, gentle, loyal, hard-working, diligent, tenacious, conscientious, initiative, positive thinking, discipline, anticipatory, initiative, visionary, earthy, passionate, dynamic, efficient / devotion / dedication, self-control, productive, friendly, love of beauty (aesthetic), sportive, steadfast, open, orderly (Suyitno, 2012; Feszterova et al., 2015).

\section{Society}

The community has an important role in the activities in this area. People who know everything that is lacking and inadequate for halal tourism area because they are giving to their local development such as clean-up activities. For the survival of a harmonious society will certainly cooperate with the government by conducting environmental awareness activities both in the neighborhood and the environment to achieve calm and serene life. The main priority of character formation of students concerned about the environment that is held clean the village activity committed by all good citizens of school age to adulthood. These activities would motivate people to further improve environmental hygiene that will also benefit both from the community and the government (Masud et al., 2017).

\section{Government}

The government has a role in creating a clean environment in an area, especially when Lombok is one of halal tourism destinations. They should pay attention to the facilities and infrastructure to support the cleanliness of the tourist environment by giving counseling to the community as well as maintaining the culture and customs of East Lombok became the attraction for tourists. Environmental care activities implemented by the government and the attention also to all levels of society is the presence to take garbage around the residents. The establishment of a clean environment certainly creates sustainable development that brings a positive impact on the government and society of Lombok (Nasibulina, 2015).

\section{Conclusion}

Based on the discussion above, it can be concluded that the developing student's character of environmental cares in the halal tourism area in East Lombok was: 1) Ulama/Tuan Guru has a very high position in order of life in East Lombok Regency. Ulama/Tuan guru become a role model because of an example is given in accordance with syariat Islam and pay attention to the environment. 2) Parents are the environment that shapes the character of the child so that it can be applied in the life of society. 3) Teachers 
can develop positive characters in students through extracurricular activities as well as foster a sense of environmental care. 4) The government has an important role in disseminating to the public about halal tourism but the community retains the character that exists in people's lives without changing the existing order. 5) The community is the person who is involved in the activities that exist in the life of the community of course also consider the environmental conditions in order to remain beautiful and far from the dirty word to be an example of the community of a region with one community in other areas, especially in East Lombok Regency.

\section{References}

Al-Anwari, Amirul Mukminin. (2014). "Strategi Pembentukan Karakter Peduli Lingkungan di Sekolah Adiwiyata Mandiri.” TA’DIB, Vol. XIX, No. 02, Edisi November 2014.

Arthur, James. (2011). "Personal Character and Tomorrow's Citizens: Student Expectations of their Teachers." International Journal of Educational Research 50 (2011) 184 - 189. University of Birmingham, UK.

Dianti, Puspa. (2014). “Integrasi Pendidikan Karakter Dalam Pembelajaran Pendidikan Kewarganegaraan Untuk Mengembangkan Karakter Siswa.” Jurnal Pendidikan Ilmu Sosial, Vol. 23 No.1, Edisi Juni 2014.

Duman, Teoman. (2011). "Value of Islamic Tourism Offering Perspectives From the Turkish Experience. World Islamic Tourism Forum (WITF), Kuala Lumpur, Malaysia, 12-13 July 2011.” International Burch University Sarajevo, Bosnia and Herzegovina.

Fahmy, Rahmi, Bachtiar, Nasri, Rahim, Rida dan Malik, Melini. (2015). "Measuring Student Perceptions to Personal Characters Building in Education: An Indonesian Case in Implementing New Curriculum in High School." 2nd Global Conferense on Business and Social Science-2015, GCBSS-2015, 17-18 September 2015, Bali, Indonesia.

Firdausi, Izza, Marantika, Stanijuanita, Firdaus, Zein Nidaulhaq, dan Sajidah, Rifqah. (2017). "Lombok: Halal Tourism as a New Indonesia Tourism Strategy." 4th International Conference on Humanities, Social Sciences and Education (ICHSSE-17) March 13-14, 2017 Dubai (UAE).

Feszterova, Melania and Jomova, Klaudia. (2015). "Character of Innovations in Environmental Education. Procedia - Social and Behavioral Sciences 197 ( 2015 ) 1697 - 1702." 7th World Conference on Educational Sciences, (WCES-2015), 05-07 February 2015, Novotel Athens Convention Center, Athens, Greece. Constantine the Philosopher University, Faculty of Natural Sciences. Slovakia.

Kumbara, A. A. Ngr Anom. (2008). “Konstruksi Identitas Orang Sasak Di Lombok Timur, Nusa Tenggara Barat.” Humaniora, Vol. 20 No. 03, Edisi Oktober, Hal 315-326.

Lubis, Adlan Fauzi. (2015). "Hidden Curriculum dan Pembentukan Karakter (Studi Kasus di Madrasah Aliyah Pembangunan UIN Jakarta).” Tesis. Program Pendidikan Agama Islam Fakultas Ilmu Tarbiyah dan Keguruan UIN Syarif Hidayatullah Jakarta.

Marlina, Murni Eva. (2013). “Kurikulum 2013 Yang Berkarakter.” JUPIIS, Vol. 5 No. 2. Edisi Desember 2013.

Masud, Muhammad Mehedi, Aldakhil, Abdullah Mohammed, Nassani, Abdelmohsen A, Azam, Mohammad Nurul. (2017). "Community-based Ecotourism Management for Sustainable Development of Marine Protected Areas in Malaysia”. Ocean \& Coastal Management.

Nasibulina, Anastasia. (2015). "Education for Sustainable Development and Environmental Ethics. Procedia - Social and Behavioral Sciences 214 ( 2015 ) 1077 - 1082." Worldwide trends in the development of education and academic research, 15 - 18 June 2015. East Siberia State University of Technology and Management. Russia.

Orenstein, Daniel E. and Pinsley, Shach Dalit. (2017). "A Comparative Framework for Assessing Sustainability Initiatives at the Regional Scale.” World Development. Technion - Israel Institute of Technology, Haifa, Israel. 
Paneand, Murty Magda and Patriana, Rina. (2016). "The Significance of Environmental Contents in Character Education for Quality of Life.” Procedia - Social and Behavioral Sciences 222 (2016) 244 - 252. Bina Nusantara University, Indonesia.

Ramdani, Zuhud dan Zamroni. (2014). "Integrasi Pendidikan Karakter dalam Pembelajaran IPS di MTsN Model Selong Lombok Timur.” Jurnal Ilmu-Ilmu Sosial, Vol. 11, No. 1 104-117. Program Pascasarjana Universitas Negeri Yogyakarta.

Rokhman, Fathur, Syaifudin, Ahmad dan Yuliati. (2014). "Character Education For Golden Generation 2045 (National Character Building for Indonesian Golden Years)." Procedia - Social and Behavioral Sciences 141 ( 2014 ) 1161 - 1165. Semarang State University, Indonesia.

Rolina, Nelva. (2014). "Developing Responsibility Character for University Student in ECE through Project Method." Procedia - Social and Behavioral Sciences 123 (2014) 170- 174. Yogyakarta State University, Indonesia.

Saaty, T. L., (2008). “Decision Making with the Analytic Hierarchy Process.” Int. J. Services Sciences. Vol. 1, No. 1 Hal $83-98$.

Shernoff, David J., Kelly, Sean, Tonks, Stephen M., Anderson, Brett, Cavanagh, Robert F., Sinha, Suparna, Abdi, Beheshteh. (2016). "Student Engagement as a Function of Environmental Complexity in High School Classrooms." Learning and Instruction xxx (2016) 1-9.

Sobri, Ahmad Yusuf. (2015).”Menumbuhkan Nilai Karakter Siswa Di Sekolah.” Universitas Negeri Malang.

Sturm, Rachel E., Vera, Dusya and Crossan, Mary. (2016). "The Entanglement of Leader Character and Leader Competence and its Impact on Performance." The Leadership Quarterly xxx (2016) xxx-xxx. United States.

Sulhaini, Saufi, Akhmad dan Rusdan. (2017). "Developing Halal Tourism Destination: Investigating Lombok’s Potentials from Dstination marketing Perspective.” In Saufi A., Andilolo I.,Othan N., Lew A. (eds) Balancing Development and Sustainability intourism destinations. Springer, Singapore.

Suyitno, Imam. (2012). "Pengembangan Pendidikan Karakter Dan Budaya Bangsa Berwawasan Kearifan Lokal.” Jurnal FBS Universitas Negeri Malang.

Tahir, Zalina Mohd, Hasan, Norihan Abu and Othman Nooraini. (2013). "Performance Measurement for Extracurricular Management at Secondary School Level.” UTM International Campus, Malaysia.

Undang-Undang Republik Indonesia Nomor 20 Tahun 2003 tentang Sistem Pendidikan Nasional.

Ülger, Mehmet, Yiğittir, Süleyman and Ercan, Orhan. (2014). “Secondary School Teachers' Beliefs On Character Education Competency." Procedia - Social and Behavioral Sciences 131 (2014) 442 - 449. Turkey.

Vasilyeva, Elena N, and Shcherbakov, Andrei V. (2016). "Parental Roles and Types of Parentings as Determinants of a Preschooler's Emotional and Personal well-being." Annual International Scientific Conference Early Childhood Care and Education, ECCE 2016, 12-14 May 2016, Moscow, Russia. Procedia - Social and Behavioral Sciences 233 ( 2016 ) 144 - 149.

Zamroni. (2011). “Dinamika Peningkatan Mutu.” Yogyakarta: Gavin Kalam Utama.

Zuchdi, Darmiyati, Prasetya, Zuhdan Kun dan Masruri, Muhsinatun Siasah. (2010). "Pengembangan Model Pendidikan Karakter Terintegrasi Dalam Pembelajaran Bidang Studi Di Sekolah Dasar”. UNY : Yogyakarta. 